\title{
MULTILINGUALISM AND THE EDUCATION OF MINORITY CHILDREN ${ }^{*}$
}

\author{
Por \\ Tove Skutnabb-Kangas**
}

\section{RESUMEN}

Lingüicismo, o sea el dominio de una lengua a costa de sacrificar otras, es el reflejo de una ideología asociada con el racismo, ya que la mayoría de casi 200 naciones son oficialmente monolingles, a pesar de que su población habla entre 4,000 y 5,000 idiomas. Al analizar el éxito de las metas bilingules de los programas educativos de varias naciones, se demuestra que en los países europeos, y en aquéllos de influencia europea, no organizan la educación de las minorías infantiles para que tengan éxito en convertirse en bilingües. Por el contrario, culpan a los mismos niños, a sus padres, a los grupos a los que pertenecen y a su cultura, por este fracaso. La autora propone que debe ser responsabilidad de los sistemas educativos, en todo el mundo, ayudar a que esos niños sean bilingües. Ofrece una declaración acerca de los derechos humanos lingúísticos de los niños para contrarrestar el linguicismo. La autora concluye que no es un problema de información, sino uno relacionado con la estructura del poder; por lo tanto, es responsabilidad de los lingüistas aumentar la información. Sin embargo, salvo que se hagan las preguntas adecuadas en las investigaciones y se responda a los porqués, se podría estar apoyando al racismo y al lingüicismo.

\footnotetext{
${ }^{1}$ Previously published in Phillipson, Robert and Skutnabb-Kangas, a Tove, 1986, Linguicism rules in education, Roskilde, Roskilde University Centre, Institute VI, 42-72. Thanks to Eduardo Hernández Chávez, Kahombo Mateene, Chris Mullard, D.P. Pattanayak, Markku Peura and Robert Phillipson for inspiring discussions and insights. Of course, none of them is responsible for the results. Thanks to Robert, too, for helping to nativize the language.

* The editors gratefully acknowledge Multilingual Matters Lud. (Clavedon, England) and Dr. Skutnabb-Kangas for permission to reproduce this article previously published in T. Skutnabb-Kangas and J. Cummins, Minority Education, From Shame to Struggle, 1988.

Los editores especiales de éste número agradecen a Multilingual Matters Led. (Clavedon, England) y a la Dra. Skutnabb-Kangas, por su autorización para reproducir este artículo, publicado anteriormente en : Skutnabb-Kangas y J. Cummins. Minority Education, From Shame to Struggle 1988.

** Dr. Skutnabb-Kangas obtained two doctorates from the University of Helsinki. Her research focuses on linguistic imperialism. Dr. Skutnabb-Kangas has conducted research in Lund, Sweden, Harvard, U. S. A. and Roskilde, Denmark where she has lived since 1979.

La Dra. Skutnabb-Kangas obtuvo dos doctorados de la Universidad de Helsinki. Su investigación se centra en el imperialismo lingüístico. Ella ha investigado en Lund, Suecia; Harvard, E. U.; y en Roskilde, Dinamarca, donde ha residido desde 1979.
} 


\section{AIISTRACT}

Linguicism, the domination of one language at the expense of others, is a rellection of an ideology, associated with racism. The majority of almost 200 states of the world are officially monolingual, yet, these states contain speakers of some 4,000 to 5,000 languages. A comparative analysis of the success of educational jrograms in different countries in reaching the goals of bilingualism, shows that most European and europeanized countries do not organize the education of minory children so that they will succeed in becoming bilingual. Instead, the ohildren themselves, their parents, their group and their culture are blamed for the failure. In the author's opinion, it should be the duty of the educational systems globally to help these children to become bilingual. To counteract linguicism, a declaration of children's linguistic human rights is proposed. The autor concludes that it is not a question of information but one of power structure. Thus, it is the job of linguists to produce information, but unless the right questions are asked in their research and why, their arguments might be supporting linguicism and racism.

A linguistic science wich is aware of these political involvements can only be militant. And it is the duty of linguists in their respective countries and regions to assume responsability for this task, this struggle for the defense and development of their own language and cultures.

(Postface to L.-J. Calvet, Linguistique et Colonialisme).

\section{INTRODUCTION}

The topic of multilingualism and the education of minority children is fascinating to work with in several different ways:

- it is a socially important -and controversial-topic, with immediate implications for most societies in the world. It forces the researcher to penetrate questions of ethnics and the philosophy of science more deeply than do many other areas of inquiry, when pondering over the relationship between research and policy.

- it is multidisciplinary and problem-oriented, and forces the researcher to familiarize herself with many disciplines, in addition to her original one(s), and to ponder over the relationship between the definitions of social reality inherent in different disciplines.

In this chapter it is possible only to introduce some of the issues. Ihope, though, that both their fascination and their complexity become clear and that the reader is intrigued and wants to find out more. The chapter starts by presenting the tension between the fact that a majority of the fewer than 200 states of the world are 
officially monolingual (have one official language only), and the fact that these states contain speakers of some 4-5,000 languages. Is state monolingualism, then, a stupid and irrational state of affairs, or a rational necessity? Is monolingualism in fact a reflection of an ideology, akin to racism, namely linguicism, the domination of one language at the expense of others (see a more detailed definition later), or is it a sign of a mature state which has reached far in an inevitable but at the same time desirable development?

Those individuals whose mother tongues do not happen to be official languages in the countries where they live, have to become bilingual (or multilingual). If they want to be able to speak to their parents, know about their history and culture, know who they are, they have to know their mother tongue. If they want to get a good education (wich is usually not available in their own language, at least not to the same extent as in the official language) and if they want to participate in the social, economic and political life of their country, they have to know the official language. It should be the duty of the educational systems to help them become bilingual, since bilingualism is a necessity for them, and not something that they themselves have chosen. The next question is: Does education in fact try to do so or not? In order to examine this question, definitions of both a mother tongue and of bilingualism/multilingualism are needed. The definitions used by the educational authorities are then examined, so as to see whether or not they reflect linguicism. In order to counteract the threat of linguicism, a declaration of children's linguistic human right is proposed.

The next section of the chapter introduces a way of comparing the success of educational programmes in different countries in reaching the goal of bilingualism, which is a necessary goal for minority children. First it presents several types of programmes, and then it goes on to compare them in terms of factors which are necessary as preconditions for succeeding in making children bilingual. The analysis shows that most European and Europeanized countries do not organize the education of minority children so that they will succeed in becoming bilingual.

The last section, before the conclusion, examines who has been blamed for the failure, the children themselves (and their parents, their group and their culture) or the linguicist societies -and the conclusions are not especially flattering for us. At the same time I hope that they will be provocative enough for the reader to start to examine her/his own society and its linguicism.

\section{MONOLINGUALISM OR MULTILINGUALISM?}

The large majority of the countries in the world are de facto multilingual (in the sense that several languages are spoken natively inside their borders, like Nigeria, with over 500 languages, or India with over 1,600 mother tongues claimed by its people). It is inevitable that most countries should be multilingual: the 
number of independent countries is less than 200 , while the number of languages spoken in the world pobably is between 4,000 and 5,000 depending on how a language is defined.

An example of monolingual country (where only one language is spoken natively) is Iceland, with is 240,000 inhabitants. There are no indigenous minorities and no immigrants. Even people who come to stay because they are married to Icelanders mostly learn Icelandic, and their children become native speakers of Icelandic (even if some of them hopefully become native speakers of another language in addition to Icelandic). But this type of monolingual country is an exception in our world.

Just like countries, individuals can be monolingual or bi- and multilingual. A monolingual is a person who "knows" only one language, whatever that means. Obviously almost everybody, excluding very small children, knows at least a few words of other languages, but they would not call themselves multilingual because of that. Maybe it is easiest to define amonolingual in a negative way: amonolingual is a person who is NOT bi- or multilingual. We shall define bilingualism later in the chapter. There are more multilinguals than monolinguals in the world. Monolingual people are thus a minority in the world, but many of them belong to a very powerful minority, namely the minority which has been able to function in all situations through the medium of their mother tongue, and who have therefore never been forced to learn another language. The majority of multilinguals are multilingual not because they thought that multilingualism was so desirable that they consciously wanted to become multilingual. It is rather because all those people whose mother tongues have no official rights in their country have been forced to learn other language in addition to their own. But since they have been forced precisely because of their powerless status (they have not been able to demand official rights for their own language), this means that they as a group have less power than monolingual. Reagan does not need to know any of the languages spoken in the USA except English, while native Americans and Chicanos need to learn English in addition to their mother tongues.

But perhaps those who are monolingual in the preesent world need not learn other languages because their mother tongues (English, Chinese, Russian, French, etc.) are so much better and so much more developed than other languages? Perhaps "smaller" languages are small because they are in fact somehow more primitive? From a linguistic point of view all languages spoken natively by a group of people have equal worth. All are logical, cognitively complex and capable of expressing any thought, provided enough resources are devoted to cultivation (creation of new lexical items, among other things). There is no such thing as "primite languages". On linguistic grounds all languages could have the same right, the same possibility of being learned fully, developed and used in all situations by their speakers. But in practice we know that this is far from the case. 


\section{MULTILINGUALISM AND THB EDUCATION}

Different languages have different political rights, not depending on any inherent linguistic characteristics, but on the power relationship between the speakers of those languages.

The political rights or lack of rights of any language cannot be deduced from linguistic considerations. They are part of the societal conditions of the country concerned, and can only be understood in their historical context, by studying the forces which have led to the present sociopolitical division of power and resources in the societies concerned.

This is also true of cultural attitudes towards monolingualism and multilingualism. These vary on a continuum: at one end monolingualism is seen as a desirable norm; at the other end multilingualism is seen as the normal state to affairs. Granted the number of languages in the world, most countries and people should, of course, be closer to the multilingualism end of the continuum in their attitudes, and in fact most countries might be placed there. But there are some very powerful exceptions, namely most European countries and, especially, most Europeanized countries. It seems that the extreme monolingualist ideology is very strong in Europeanized countries, those countries, which have been colonized by European settlers to such an extent that a virtual extinction of the indigenous populations has been attempted, either "only" physically (like parts of Australia, for instance Tasmania, or some parts of Latin America) or both physically and linguistically/culturally (North America, New Zealand, Australia). Like-wise, this strong monolingual ideology also prevails in most former imperial European countries which are the sources of the languages of the former colonizers (Britain, France, etc.).

These negative attitudes towards multilingualism pertain both in relation to official multilingualism in a country (which is seen as divisive for the nation) and to individual multilingualism. Being bilingual has in several countries, especially the United States, been used almost as a synonym for being poor, stupid and uneducated. And it is true that coming from a linguistic minority in a monolingually oriented country has often meant misery and non-education.

For an individual, monolingualism almost inevitably means monoculturalism and monoculism, being able to see things with one pair of glasses only and having a poorly developed capacity to see things from another person's or group's point of view. It mostly means knowing not more than one culture from the inside, and therefore lacking relativity.

For a country, official monolingualism in the majority of cases means that all the minorities are oppressed and their linguistic human rights are violated.

To me monolingualism, both individual and societal, is not so much a linguistic phenomenon (even if it has to do with language). It is rather a question of a psychological state, backed up by political power. Monolingualism is a psycho- 
logical island. It is an ideological cramp. It is an illness, a disease which should be oradicated as soon as possible, because it is dangerous for world peace. It is a reflection of linguicism.

\section{LINGUISCISM}

Linguicism is akin to the other negative - isms: racism, classism, sexism, ugeism. Linguicism can be defined as ideologies and structures which are used to legitimate, effectuate and reproduce an unequal division of power and resources (both material and non-material) between groups which are defined on the basis of language (on the basis of their mother tongues).

D. P. Pattanayak, the Director of the Central Institute of Indian Languages, says in a powerful article (1986) that the Western way of looking at multilingualism is something like this: a country should ideally be monolingual. If it is officially bilingual, that is a pity but one can live with it. If it has three or more languages, it is underdeveloped and barbaric. In order to become civilized. it should strive towards becoming monolingual.

But if there are many more languages than countries, and if many countries decide to be officially monolingual, what happens to all the other languages and to their speakers? Should the speakers of these languages become monolingual, too? And if so, in which language should they become monolingual, their own or the language that power élite in the country has decided should be THE language of that country? The last alternative would mean that thousands of languages would become extinct. Or should the speakers of other languages become bilingual? If so, what is the best way of become bilingual for a minority language speaker? Specifically, in which language should the minority child be taught, predominantly in her own language, or predominantly in the majority language, in order to become a competent bilingual.

The controversy about this, both about the goal (monolingualism or multilingulism) and about the means (operationalized as mother tongue medium education or second/foreign language medium education) is the main topic of this chapter. While we go along, we shall examine both the goals and the means, in order to see the extent to which they are flect linguicism.

We could tentatively present the positions in Europe and Europanized countries in the following, extremely simplified way:

Minorities (like many non-European and non-Europeanized countries) think that genuine multilingualism is a perfectly normal and desirable state. It is a possible and desirable to have multilingualism as the linguistic goal in the education of all children.. Mother tongue medium education is often 
a good way to bilingualism/multilingualism for minorities. Learning one's mother tongue is a human right which does not need any futher legitimation. Majorities $^{2}$ think that monolingualism in the majority language is the nomal and desirable state. Societal multilingualism is divisive and should not be a goal. If individual multilingualism has to be accepted, the emphasis should be on the learning of the majority language. If mother tongue medium education for minorities has to be accepted, the only legitimation for it is that it leads to increased proficiency in the majority language.

\section{THE GOAL OF EDUCATION FOR LINGUISTIC MINORITY CHILDREN}

If you want to have your fair share of the power and the resources (bothmaterial and non-material) of your native country, you have to be able to take part in the democratic processes in your country. You have to be able to negotiate, try to influence, to have a voice. The main instrument for doing that is language. You must be able to communicate with your fellow citizens in order to be able to influence your own situation, to be a subject in your life, not an object to be handled by others. Language is the main instrument for communication. If you live in a country with speakers of many differente languages, you have to share at least one language with the others, in order for a democratic process to be possible. And if the language most widely spoken by your fellow citizens (either because it is the mother tongue of the majority, or because the power elite' has decided that it will be the lingua franca) is NOT your mother tongue, you belong to a linguistic minority in your country. That means that you have to become (at least) bilingual in order to participate.

In a democratic country, it should be the duty of the school system to give every child, regardless of linguistic background, the same chance to participate in the democratic process. If this requires that (at least) some children (i.e. the linguistic minority children) become bilingual or multilingual, then it should be the duty of the educational system to make them bilingual/multilingual, as individuals (as opposed to the country being multilingual).

\footnotetext{
${ }^{2}$ When using terms minority/majority, I define them in terms of power relationships, not (entirely) in terms of numbers. If "majority" is used to denote a numerically strong but politically weak group (like Blacks in South Africa), this is market by calling them a powerless majority, implying that they have the capacity to become a "real" majority, i.e. to again access to their fair share of power, wich would be "more" than the power of the numerical minorities, among them the white power-minority. But using labels like "majoriry" and "minority" is unsatisfactory from another point of view, too: is obscures the class differences both between and, especially, within these groups, and makes them appearmuch more homogeneous than they are. The enormous heterogeneity of boch "majorities" and "minorities" should be constantly borne in mind. Within each group there are contradictory and conflicting views, and this is one source of change in society.
} 
If Western attitudes really are inclined towards monolingualism (and I find no convincing arguments to refute Pattanayak's analysis), what are the chances that European and Europeanized countries will come up with good solutions to question about the education of minority children, solutions which would promote multilingualism? Slight, as I see it. Monolingualism does not prevent some knowledge of other languages, provided these are "modern" and "European" and have been learned at school as part of becoming "educated". If monolingualism (with some knowledge of other languages) is the explicity or at leat implicity desirable and accepted societal norm, there is an inherent conflict between supporting that norm, and organizing minority (or majority) education so that it would lead to high levels of bi-or multilingualism.

But this conflict is seldom discussed openly. In fact, most European countries have at least some passages in their declarations of goals for the education of minorities which refer to bi-or multilingualism. Mostly it is discussed as a societal phenomenon ("Britain is multilingual"), and here it means only that several languages are spoken in a country. This is often only stating a fact, not declaring a wish ("OK, there are several languages spoken in this country, and since we cannot really do much about it, we had better accept it and try to see if there is anything positive in it"). Bilingualism/multilingualism is seldom declared as a goal for the educational system. If it is, then the language learning emphasis is put on the learning of the majority languaje (L2=languaje two, the second or foreign languaje) by the minority children. The part of their bilingualism which has to do with the minority language ( $\mathrm{L} 1=$ the first language, the mother tongue), again states the fact, but does not declare a wish ("OK, they do speak that minority language, but obviously they need to learn L2, English/German/Dutch etc.: that is the most important thing in their education. If learning English makes them bilingual, then the goal of education must be to make them bilingual, because they have to learn English").

It thus seems that both minorities and majorities agree that minority children should be given the opportunity to learn the majority language in school. But they disagree about the learning of the minority mother tongue. Many minorities think that their mother tongues should have the same rights, also in school, as majority people's mother tongues do. Majorities act as if minority mother tongues were of less value (cultural linguicism), and emphasize educational efforts geared towards the learning of the majority language (institucional linguicism).

\footnotetext{
${ }^{3}$ Terms like "power élites" are often used in vague ways, as synonymous with "ruling class" or "decision-makers". The vagueness makes it difficult to distinguish between groups in power in less and more democratic political systems. Giddens (1973:118-127) has an iluminating discussion of the differences, from the "strongest case" of a "ruling class" to the "weakest", i.e. most democratic, with "leadership groups". All of these groups can decide about the official language or the language of instruction. The decisions tend to be more beneficial for minorities in the "weaker" formations.
} 


\section{DEFINITIONS OF MOTHER TONGUE}

Before we can continue our discussion, we have to define what a mother tongue is. This gives us a better opportunity to assess whether minority mother tongues have the same rights or whether majority mother tongues are given more institutional support (institutions in the abstract sense of laws and regulations, and in the concrete sense of day-care centres, schools, etc.).

There are several different ways of defining a mother tongue. I use four different criteria for the definitions: Origin, Competence, Function and Identification (see Table 1.1).

\section{TABLE 1.1 Definitions of mother tongue}

Criterion Definition

Origin

Competences

Function

Identification

a) internal

b) external the language (s) one learned first the language (s) one knows best the language (s) one uses most the language (s) one identifies with the language (s) one is identified as native speaker of by others

(Skutnabb-Kangas, 1984:18)

I have three thesis about the definitions:

1.The same person can have different mother tongues, depending on which definition is used

2. A person's mother tongue can change during her lifetime, even several times, according to all other definitions except the definition by origin.

3. The mother tongue definitions can be organized hierarchically according to the degree of linguistic human rights awareness of a society.

I am a good example of the first thesis myself. My mother tongue is Swedish according to the definition by origin, because both my bilingual parents spoke it to me when I was a baby. But I am bilingual in Finnish and Swedish according to the same definition (see table 2.2) because I myself used both languages side by side from the very beginning. My mother tongue is Finnish according to the definition by competence; I feel that it is the language I know best (even if I know Swedish, too, just as well as any monolingual Swedish academic). My mother tongue would be English (or possibly English and Danish) according to the definition by function (I speak mostly English-in addition to three other language- 
at home, and read and write English more than other languages, and I live in Denmark). And according to all identification definitions I have two mother ungues, Finnish and Finland Swedish. This also ilustrates the second thesis, hecause both English and Danish have come into the picture through emigration and marriage, i.e. changes.

The third thesis about the definitions is the most interesting one from the point of view of linguicism. According to my view, the definition by function is the most primitive one ("this Turkish child speaks German/Dutch/English all day long at the day-care centre/in school, much more than Turkish, she even uses German with siblings, so German/Dutch/Danish/English must be the child's mother tongue"). Use of this definition does not consider the fact that most minority children are forced to use an $\mathrm{L} 2$ because there are no facilities in their mother tongue. The children and their parents have not themselves been given a chance to choose freely, from among existing alternatives, which language they would like to use in day-care and school. This definition is, explicitly or implicitly, used in educational institutions in many European immigration countries.

When the degree of awareness rises a bit, the next definition, also pretty primitive, is used, namely the definition by competence ("the Turkish children could not even count in their so-called mother tongue" says a well-known linguist, implying that Swedish, in which the children had been taught how to count, was their mother tongue, because they knew it better than Turkish). Use of this definition fails to consider that a poor proficiency in the original mother tongue is a result of not having been offered the opportunity to use and leam the original mother tongue well enough in those institutional settings where the children spent most of their day (day-care centres, schools, organized after-school activities). A poor competence in the original mother tongue (which is a result of the neglect of the mother tongue in institution earlier on, i.e. a result of earlier oppression) is then often used to legitimize additional oppression. The child is labelled as a majority language speaker, or she is denied teaching in the original mother tongue on the grounds that she does not know it well enough or because she knows the majority language better.

Use of a combination of definitions by origin and identification shows the highest degree of linguistic human rights awareness: the mother tongue is the language one has learned first and identifies with.'

Use of a definition of function or competence in cducational institutions when defining a minority child's mother tongue reflects cultural and institutional linguicism. It can be open (the agent does not try to hide it), conscious (the agent knows about it), visible (it is easy for non-agents to detect) and actively actionoriented (as opposed to merely attitudinal). All this is typical of the early phases of the history of minority education, as described in the later sections of this chapter. Or it can be hidden, unconscious, invisible and passive (lack of support 
rather than active opposition), typical of the later phases of minority education development. Those countries which have developed the more sophisticated, culturally (rather than biologically) oriented forms of racism (ethnicism-see Mullard, 1985b), typically also exhibit this more sophisticated form of linguicism, a linguicism which blames the victim in subtle ways, by colonizing her consciousness.

\section{RESULTS OF INSTITUTIONAL AND CULTURAL LINGUICISM FOR MINORITY MOTHER TONGUES}

The above recommended mother tongue definition implies that the language identified with is the original mother tongue, the language learned first. But in a society with institutional and cultural linguicism and discrimination, not all minority children are allowed to identify positively with their original mother tongues and cultures.

Many minority children are being forced to feel ashamed of their mother tongues, their parents, their origins, their group and their culture. Many of them, especially in countries where the racism is more subtle, not so openly expressed, take over the negative views which the majority society has of the minority groups, their languages and cultures. Many disown their parents and their own group and language. They shift identity "voluntarily", and want to be German, Dutch, American, British, Swedish, etc.

Often this does not work either. The child's new majority identity is not acceoted by everybody. This is generally expressed more openly in the years after the minority youngsters reach puberty, and it is more common with youngsters who do not look like the stereotype of what a "real" German, Dutch, Swede, Norwegian, etc. person "should" look like, and/or whith youngsters whose accent does not sound "native". The minority youngster then often hears: "You are not one of us, you are not a real Swede/American/Dutch/German/Dane, etc. you are a Finnish devil/a Turkshit/a damn paki, etc."

The child has then "voluntarily" disowned her original identity, but the new identity is not accepted by all the people from the majority group either. There is a conflict between the internal and external identification. The youngster is not accepted, at least nost unconditionally, by the majority group, with which she has been forced to identify (but whose language and culture she has not been given the opportunity to learn "fully": see Cummins, 1984). At the same time the road back to her own group is often closed too, not only psychologically (= she does not want to identify with the "dirty Turks" or "aggressive silent Finns"), but often also linguistically and culturally. The child no longer knows (or has never had the chance to learn) the original mother tongue "properly". Nor does she have all the components of cultural competence in the original culture (Phillipson \& SkutnabbKangas, 1983). 


\section{DECLARATIONS OF CHILDREN'S LINGUISTIC HUMAN RIGHTS}

In order to avoid this type of situation, all those institutions, educational and otherwise, which now function in the way described above vis- $d$-vis minority children and their mother tongues, should be changed. Majority cultures, which now degrade minority children's languages and cultures, should be changed. In order to make the demands for changes more concrete, we need a declaration of children's linguistic human rights.

\section{The declaration of children's linguistic human rights}

1. Every child should have right to identify positively with her original mother tongue(s) and have her identification accepted and respected by others.

2. Every child should have the right to learn the mother tongue(s) fully.

3. Every child should have the right to choose when s/he wants to use the mother tongue(s) in all official situations (Skutnabb-Kangas, 1986:160).

Not to live up to these demands for minority children is linguicism. If Dutch, West German, Swedish, British, etc. day-care centres and schools, actively or through passivity and lack of positive action, prevent minority children from being able to identify positively with their mother tongues, then they function in a linguicist way. If in the same vein they prevent minority children from learning their mother tongues fully and from using them in all official situations, including day-care centres and schools, then these institutions also function in a linguicist way. If the education of minority children is not discussed in these terms, i.e. if the Swedes, Norwegians, Dutch, Germans, etc. are not even aware of or deny the fact that they are suppressing minority children's basic human rights every day, then the Dutch, German, Swedish, British, etc. cultures are linguicist vis-à-vis minority children and their languages.

All the demands formulated in the declaration of children's linguistic human rights are met to a very large extent in relation to majority children. Nobody questions their right to identify positively with their mother tongue,to learn it fully or to use it in official situations, for instance in schools. For majority children these rights are so self-evident that they may never think of them as human rights. Some people mignt think that it cannot be a human right to use one's mother tongue in all official situations, for instance. But even if one did not accept that the rights in the declaration are legitimate human rights, there is no way of denying the fact that majority and minority mother tongues do not enjoy the same rights in the educational systems of most European and Europeanized countries. Groups defined on the basis of their mother tongues thus have unequal access to educational resources, i.e. these educational systems reflect linguicism. 


\section{DEFINITIONS OF BILINGUALISM}

Above we claimed that the majorities are mostly interested in the part of the bilingualism goal wich has to do with the learning of the majority language by minority children. The mother tongues of the minority children are tolerated as parts of the curriculum only if the teaching of them leads to a better proficiency in the majority language. The minorities themselves, partly as a result of this, have to put a strong emphasis on the learning of the mother tongues as a linguistic human right. But the minorities do, of course, want their children to learn the majority languages fully too. We want our children to become bilingual, not monolingual or strongly dominant in either of the two language. One of the confusing facts has been that many majority educational authorities claim that they want our children to become bilingual too. But when this claim is analysed, it transpires that the definitions used by majorities and minorities of bilingualism as the educational goal are different. That is one of the reasons why it is imperative to define "bilingual" every time the term is being used. There are literally hundreds of definitions. In Table 1.2. I organize them according to the same criteria which I used in the mother tongue definitions, and give a sample.

When majority educational authorities talk about bilingualism as a goal for the education of minority children, they seem to mean either a non-demanding competence definition (for instance $2 \mathrm{~d}$ or $2 \mathrm{e}$ ) or the most general function definition (uses two languages). We minorities would rather like to use a combination of 2,3 and 4, a definition which makes sure that the speaker has the chance to learn and use both languages at a very high level and to identify positively with both. Again we see that the definitions used by the majority authorities confirm the picture of linguicism: there are almost no demands made on the minority child's competence in her mother tongue.

My own definition is specifically planned to suit inmigrant and indigenous minority children. The goal of minority education should be to make the children bilingual according to this definition:

"A speaker is bilingual who is able to function in two (or more) languages, either in monolingual or bilingual communities, in accordance with the sociocultural demands made on an individual's communicative and cognitive competence by these communities and by the individual herself, at the same level as native speakers, and who is able positivel to identify with both (or all) language groups (and cultures) or parts of them". (Skutnabb-Kangas, 1984:90).

The implications of this definition for the educational system are farreaching, and should be compared with the implications of less demanding definitions (for more detail see Skutnabb-Kangas, 1984). 
TABLE 1.2 Definitions of bilingualism

\begin{tabular}{|c|c|}
\hline Criterion & Definition \\
\hline 1. Origin & $\begin{array}{l}\text { A Speaker is bilingual who: } \\
\text { a) has learned two languages in the family from } \\
\text { native speakers from the beginning } \\
\text { b) has used two languages in parallel as means of } \\
\text { communication from the beginning }\end{array}$ \\
\hline 2. Competence & $\begin{array}{l}\text { a) has complete mastery }{ }^{4} \text { of two languages } \\
\text { b) has native-like control of two languages } \\
\text { c) has equal mastery of two languages } \\
\text { d) can produce complete meaningful utterances } \\
\text { in the other language } \\
\text { e) has at least some knowledge and control of the } \\
\text { grammatical structure of the other language } \\
\text { f) has come into contact with another language }\end{array}$ \\
\hline 3. Function & $\begin{array}{l}\text { a) uses (or can use) two languages (in most } \\
\text { situations) (in accordance with her own wishes } \\
\text { and the demands of the community) }\end{array}$ \\
\hline $\begin{array}{l}\text { 4. Identification } \\
\text { internal }\end{array}$ & $\begin{array}{l}\text { a) identifies herself as bilingual/with two lan- } \\
\text { guages and/or two cultures (or two cultures (or } \\
\text { part of them) }\end{array}$ \\
\hline external & $\begin{array}{l}\text { b) is identified by others as bilingual/as a native } \\
\text { speaker of two languages }\end{array}$ \\
\hline
\end{tabular}

(Skutnabb-Kangas, 1984:91)

In the next section we turn to an examination of concrete educational programmes, in order to see to what extent there is a mismatch between the goals and the means in the education of minority students. If the educational systems are organized to give minority students a fair chance of becoming bilingual and succeeding in school, then the claims of linguicism are unfounded. If, on the other hand, the education is organized to prevent minority children from gaining access to the instruments (here operationalized in terms of high levels of bilingualism and a "good" education) for claiming their fair share of power and resources, and if the mother tongue (minority or majority language) plays a decisive part in the division of children into those who do and those who do not again such access, then the educational system functions in a linguicist way. 


\section{COMPARING THE SUCCESS OF EDUCATIONAL PROGRAMMES IN DIFFERENT COUNTRIES IN REACHING THE GOAL OF BILINGUALISM}

Some of the educational programmes for minority and/or majority children achieve a high degree of success (HDS) in making the children bilingual and giving them fair chance of good school achievement (see Table 1.3). Others show a low degree of success (LDS): many children do not learn any of the languages at the same level as monolinguals, or they become strongly dominant in one of the languages, i.e. they fail to become bilingual. They also show, as a group, low levels of achievement in schools, often massive failure. One of the most frequently discussed factors in explaining the difference between the two groups is which of the two languages has been used as the medium of education(ME). Paradoxically, instruction through the medium of a mother tongue can lead to either HDS or LDS. Likewise, instruction through the medium of a second language can also lead to either HDS or LDS. In order to understand this we must look both at socictal factors which determine what type of programme is chosen for different groups, and at cognitive, pedagogical, linguistic and sociological factors which determine the outcome of the instruction. It become abundantly clear from the analysis that "which language should a child be instructed in, L1 or L2, in order a become bilingual?" poses the question in a simplistic and misleading way. The question should rather be: "under which conditions does instruction in $\mathrm{L1}$ or $\mathrm{L} 2$, respectively, lead to high levels of bilingualism?"

I will analyse different types of educational programmes in very concrete terms, in order to highlight the decisive factors, under four main headings: segregation, mother tongue maintenance (or language shelter), submersion and immersion programmes. In three instances it is necessary to treat separately the programmes meant for minorities and majorities. For each programme, I assess the degree of success (high or low), the medium of education (L1 or L2) and the linguistic and societal goals of the programme. The classification of the goals builds more on factual results achieved than on declarations of intention, and many therefore not always tally with the officially declared goals. Some of the discussion that follows is also found in Phillipson, Skutnabb-Kangas \& Africa (1986).

My example of a segregation model for a majority population (in this case a powerless majority) is the Bantu education now given at the elementary level to Namibians in nine different L1s, in Namibia. Namibia is still illegally occupied by South Africa, despite the efforts of the United Nations (manifested in several declarations) to end this state of affairs. (To a certain extent also the education for Blacks in South Africa is of the same kind). Segregation programmes produce poor results, meaning scholastic failure for the majority of those who start school (and many do not), and low levels of cognitive/academic proficiency (see Cummins, 1984) in both languages. This fits with the linguistic goal, dominance in L1, and the societal goal, perpetuation of apartheid. 
My example of segregation for a minority is the education of migrant Turks in Bavaria, West Germany, through the medium of Turkish, again with levels of success. The linguistic goal is dominance in Turkish. The societal goal is to prepare the migrant pupils for forced repatriation when their parent's labour is not longer needed or when they themselves become "too expensive" or "too troublesome" for West Germany (for instance when resisting assimilation and racism by political or other means).

In contrast to segregation, mother tongue (MT) maintenance programmes which also use the children's mother tongues as ME, show high levels of success -because the linguistic goals (bilingualism) and societal goal (equity and integration) are different. An example of maintenance for a majority is the MT-medium education given in the Soviet republic of Uzbekistan to the seven main language groups, including the dominant group, the Uzbeks. Since the main groups are all in the same position educationally, with the same rights, they are here treated as together forming a majority. In Uzbekistan, where only a tiny elite was literate 70 years ago when the country was still under feudal conditions, all children now complete at least 10 years of education. The main groups have the right toeducation through the medium of their own languages, with Russian or another Uzbekian language as a second language.

Examples of maintenance for minorities are the Finnish-medium classes for Finnish migrant population in Sweden (or Spanish-medium classes for the Chicans population in the USA), who have gone through the whole comprehensive school (nine years) in Finish in Botkyrka, a suburb of Stockholm, continue their education in upper secondary schools in the more academic streams to a somewhat greater extent than Swedish youngters from the same schools (Hagman \& Lahdenper volume).

An example of submersion ${ }^{5}$ for a majority is education through the medium of a former colonial language in many African countries, for instance Zambia (Chishimba, 1984). For the vast majority of the population the results are poor, both academically and linguistically (Africa, 1980). The linguistic goal achieved is

\footnotetext{
"Mastery", of course, has sexist connotations, in addition to its (for me) negative class connotations. Many of the words many of us use unaware every day are living examples of the hidden, unconscious sexism, racism and classism in our societies. There are many good candidates even in this paper, and where they have been unavoidable (because explanations would be too long) I have at least tried to mark my distance (for instance when calling French, English and German "modem" "European" languages).

SA submersion, or sink-or-swim programme, is a programme where linguistic minority children with a low-status mother tongue are forced to accept instruction through the medium of a foreign majority language with high status, in classes where some children are native speakers of the languages of instruction, where the teacher does not understand the mother tongue of the minority children, and where the majority language constitutes a threat to their mother tongue-a subtractive language leaming situation.
} 
L1

\section{L2}

\begin{tabular}{|c|c|c|c|}
\hline $\begin{array}{l}\text { Segregation } \\
\text { LDS }\end{array}$ & $\begin{array}{l}\text { Maintenance } \\
\text { HDS } \\
\text { d }\end{array}$ & $\begin{array}{l}\text { Submantion } \\
\text { LDS }\end{array}$ & $\begin{array}{c}\text { Immension } \\
\text { HDS } \\
g\end{array}$ \\
\hline & Chicanos & Minorit & \\
\hline
\end{tabular}

Organizational factors

1 altemative programmes available

2 pupils equally placed vis-d-vis

knowlodge of ME

3 bilingual (B), trained (T) teachers

4 bilingual materials (a. 8 .

dictionaries) available

5 cultural content of material appropriate for pupils

\section{Leamer-related affective}

factors

6 low level of anxiety (supportive,

non-authoritarian)

7 high intemal motivation (not forced

to use L2, understands \& sympathetic

with objectives, responsible for own learning)-

8 high self-confidence (fair chance to

succeed, high teacher expectations)

$L I$-related linguistic, cognitive, pedagogical and social factors

9 adequate linguisticdevelopment in $\mathrm{L} 1$

(L1 taught well (W), badly (B) or not at

all in school)

10 enough relevant, cognitively demanding

subject matter provided

11 opportunity to develop L1 outside school

in linguistically demanding formal contexts $+?$

12 L2-teaching supports $(+)$ or harms $(-)$

L1 development

\begin{tabular}{|c|c|c|c|c|c|}
\hline B & B & w & w & - & - \\
\hline-7 & +7 & + & + & -7 & -7 \\
\hline+7 & - & + & $\cdot$ & + & - \\
\hline+ & + & + & + & -7 & - \\
\hline
\end{tabular}

L2-related linguistic, cognitive, pedagogical and social factors

13 adequate linguistic development in L2

(L.2 taught well (W), badly (B) or not at

all in school)

$14 \mathrm{~L} 2$ input adapted to pupil's L.2 level

15 opportunity to practise L2 in peer group contexts

16 exposure to native speaker L2 use

in linguistically demanding formal contexts

$\begin{array}{ccccccc}\text { B } & \text { B } & \text { W } & \text { W } & \text { B } & \text { B } & \text { W } \\ + & + & + & + & -7 & - & +\end{array}$

LDS $=$ low degree of success HDS $=$ high degree of success

$a=B$ antu $b=$ Turks $c=$ Uzbekistan $d=F i n n s ~ e=Z a m b i a$ f $=W$. Europe $g=$ Canada 
dominance in English for the élite, and, for the masses, dominance in their mother tongues (which the school does nothing to develop) and limited proficiency in I'nglish.

Submersion programmes for minorities are still by far the most common way of educating both indigenous and immigrant minorities in most countries in the world. Even in Sweden, where we have come a long way, some $80 \%$ of the immigrant children are educated this way, through the medium of Swedish, regardless of the fact that all immigrant organizations in every Scandinavian country demand mother tongue medium education. Most migrants, for instance in the UK and West Germany (except Turks in Bavaria who are in segregation programmes and some Greek and other migrants in maintenance programmes), undergo submersion, resulting in dominance in the majority language at the expense of the mother tongue, and poor school achievement. Societally this means assimilation for some (depending on whether the country in question allows assimilation or not) and marginalization for the many. It should, perhaps, also be added that transitional programmes ${ }^{6}$ belong to the submersion type, too; they are simply a version of submersion which is a bit more sophisticated than direct submersion (see my typology in Skutnabb-Kangas, 1984:125-133).

By contrast, Canadian immesion ${ }^{7}$ programmes, in which English-speaking majority children are educated through the medium of an L2 (mostly French, but several other languages are also in operation: see Lambert \& Taylor, 1982), lead to high level of bilingualism and success at school (Swain \& Lapkin, 1982). The societal goals include linguistic and cultural enrichement for the power majority, and increased employment prospects and other benefits for an elite. As is clear from the definition of immersion programmes, the concept cannot, by definition, be applied to minorities.

${ }^{6}$ A transitional programme is a programme where linguistic minority children with a low-status mother tongue are instructed through the medium of their mother tongue for a few years and where their mother tongue has no intrinsic value, only an instrumental value. It is used only in order for the children to leam the majority language better, and in order to give them some subject matter knowledge while they are leaming the majority language. As soon as they can function in the majority language orally, they are transferred to a majority language medium programme. A transitional programme is a more sophisticated version of aubmer sion programmes, a more "humane" way of assimilating.

${ }^{7}$ An immersion programme is a programme where linguistic majority children with a high-status mother tongue voluntarily choose (among existing altematives) to be instructed through the medium of a foreign (minority) language, in classes with majority children with the same mother tongue only, where the teacher is bilingual so that the children in the beginning can use their own language, and where their mother tongue is in no danger of not developing or of being replaced by the language of instruction-and additive language learning situation. 
To summarize so far, in all HDS contexts the linguistic goal has been bilingualism, and thesocietal goal has been apositive one for the group concemed. In all LDS contexts, the linguistic goal has been dominance in one of the languages, either L1 or L2. NOT bilingualism. The other language (non-ME) has been neglected or taught badly. The societal goal has been to keep the group (or at least most of them) in a powerless subordinate position.

Next we turn to how the programmes are organized, in order to see the extent to which they create optimal conditions for efficient L2-learning and bilingualism. The preconditions for learning L2 effectively and for becoming bilingual have been grouped into four categories, called organizational factors, learner-related affective factors, and linguistic, cognitive, pedagogical and social L1-related and L2-related factors, respectively. These factors are chosen to reflect the present views in different disciplines in relation to important or necessary preconditions for L2-learning and bilingualism.

\section{HOW DO DIFFERENT PROGRAMMES SUPPORT L2-LEARNING AND BILINGUALISM?}

We start with organizational factors. Alternative programmes (Table 1.3, factor 1) are available only in the HDS programmes, i.e. in maintenance and immersion contexts. These programmes are optional. An Uzbek or Tadjik in the USSR, a Finn in Sweden or a Chicana in the USA who wants education through the medium of Russian, Swedish or English (instead of Uzbek, Tadjik, Finnish or Spanish, respectively), can opt for that. An English-speaking Canadian child can choose between English-medium education or a French-medium immersion programme. By contrast, children in segregation or submersion programmes have no choice. Either alternatives do not even exist, as in most submersion programmes, or, if they do, children in segregation or submersion programmes are precluded from them administratively or economically.

Factor 2 covers wheter there are in the same class both native speakers of the medium of education (ME) and pupils for whom the ME is an L2. This is a normal situation in submersion programmes, disadvantaging the L2-learners. In Zambia, the pupils' class background and geographical location (urban or rural) has a decisive influence on their prior knowledge of English. In all the other programmes pupils are, in relation to prior familiarity with the ME, on an equal footing in that initially either they all know the language of instruction (segregation and maintenance) or none of them do (immersion).

The third factor shows that the HDS programmes have teachers who are both bilingual and well trained. For instance, in immersion programmes, the teacher understands everything that the English-speaking children say in English, even if she herself speaks only French to the children. Thus the children can communicate 
ull their needs to the theacher initially in their L1, and only later start doing so in 1.2 when they feel confident enough. The LDS programmes have either well Ir ained monolingual teachers who do not understand their pupils' mother tongues (nubmersion of minorities) or else the training of the teachers is inadequate, even If they are to some extent bilingual (for instance segregation, and submersion for majorities in Zambia). We consider, though, that a bilingual (mostly meaning minority group) teacher without any training is usually a better choice than a monolingual well trained teacher. This is especially so in second language contexts, where the pupil hears L2 outside school anyway. Especially in relation to small children, it is close to criminal, real psychological torture, to use monolingual teachers who do not understand what the child has to say in her mother tongue. Not giving minority teachers a good training, adjusted to the conditions in the receiving country, is one of the reflections of the institutional racism in the Westem countries. At the same time it protects the employment prospects of majority teachers, and makes minority children's failure in schools look like the children's fault, instead of the deficiency of the school system which it of course is.

Factor 4 shows that most of the LDS programmes lack bilingual materials. The materials actually used (factor 5) in them are imported or racist or both, thus imposing alien cultural values.

The learner-related affective factors suggest that a supportive learning environment and non-authoritarian teaching reduce anxiety (6). Internal motivation (7) is increased when the pupil is not forced to use L2, and can start producing L2 utterances only when she feels ready for it. Again this stresses the importance of bilingual teachers, because the child is forced to use L2 if the teacher does not understand the child's L1. High motivation is also related to an understanding of and sympathy with the educational objectives and to sharing in responsability for one's own learning (which is difficult without bilingual materials). High selfconfidence (8) is related to whether learners have a real chance of succeeding in school, and to favourable teacher expectations. One of the conditions for this is that the teacher accepts and values the child's mother tongue and cultural group, and is sympathetic with the parent's way of thinking, even though the teacher might have a different class background from the parents. There is a positive correlation between a plus-rating on these factors (low anxiety, high motivation and high selfconfidence) and the successful programmes.

The final two sets cover linguistic, cognitive, pedagogical and social languagerelated factors. Linguistic development in $L 1(9)$ is inadequate when the MT is taught badly, as in most segregation programmes (wich should not be blamed on the teachers!) or not at all, as in most submersion programmes. It should also be mentioned that a couple of hours a week of mother tongue instruction for a minority child is more therapeutic cosmetics than language teaching. 


\section{MULTIINGUALISM AND THE BDUCATION}

Enough relevant cognitively demanding subject matter (10) to promote the common underlying proficiency for all languages (CALP: see Cummins, 1984; Skutnabb-Kangas, 1984) is provided in the HDS programmes. This is done through the medium of $\mathrm{L} 1$ in maintenance and through $\mathrm{L} 2$ in immersion (where it is made sure that the children understand, and where it has been shown that they can transfer the knowledge: see Swain \& Lapkin, 1982). The input may satisfy this criterion in some segregation programmes, because the pupils at least understand the instruction. In submersion, when both language and subject matter are unfamiliar, it is less likely (for details see Skutnabb-Kangas, 1984). If the child learns how to use language as an effective instrument for thinking and problem solving in one language (by gaining a lot of relevant knowledge and using it), this capacity can also be transferred to other languages.

In addition to L1-development in school, pupils also need the opportunity to develop their MTsoutside school in linguistically demanding formal contexts (11). Otherwise they are restricted to being able to discuss everyday things in informal setting only. This opportunity exists at least to a certain extent for all indigenous groups, but not for immigrants. Some groups may therefore be able to compensate for inadequate school provision outside the school setting. A more general factor which influences whether the language leaming situation is additive (Lambert, 1975: you add a new language to your existing linguistic repertoire, without losing your mother tongue) or subtractive (another language replaces the mother tongue) is the degree to which L2-teaching supports or harms L1-development (12). Only submersion programmes threaten the MTs in this way.

Linguistic development in L2 (13) is inadequate when the L2 is badly taught, as it in all the LDS programmes. A teacher, monolingual in L2, can never be really good L2 teacher1 A good L2 teacher knows both languages.

Also relevant is the degree to which L2 input is adapted to pupil's L2 level (14). It is difficult to adapt the input in this way in immigrant submersion contexts, because the difference in the pupil's proficiency in the same class is too great. The task is relatively more feasible when no pupils are native speakers of the ME, as in Zambia.

Absence of the opportunity to practise the L2 in peer group contexts outside school (15) may be due to practicalities (immersion children do not meet many L2 children), to sheer racism (Turkish children are often avoided by German children), or to a shortage of L2 native speakers, as in Zambia, or as in Bantu education. where institutionalized racism and apartheid aggravate the situation.

Exposure to native speaker $L 2$ use in linguistically demanding formal contexts (16) depends on the existence of L2 institutions staffed by native L2 speakers. Turks in West Germany cannot escape exposure to native German, where as 
7ambians are exposed to a range of non-native Englishes, some of them appropriate regional models, some of them interlanguages (=languages spoken by learners of English) (but see Kachru, 1986)!

As we can see from the chart (Table 1.3), there is a clear difference between the programmes in that the HDS programmes with bilingualism as the linguistic goal and with positive societal goals have organized the teaching so that many of the preconditions for efficient L2 learning and bilingualism are met. The LDS programmes do so to a much lesser extent.

This comparison also functions as a validation of the way we attributed goals to the different programmes -otherwise it might have been claimed that we first looked at the results and then attributed positive goals to the HDS programmes and negative goals to the LDS programmes. Likewise, the comparison validates our claims about linguicism.

We can see that the situation for those who would want to organize minority children's education properly is tricky in those countries where the exploitation of a minority (or a powerless majority, as in Namibia) is open and brutal. Measures which under different, less oppresive conditions would be positive (like mother tongue medium education) can in the hands of an oppressive regime become instruments for segregation and apartheid.

We can also draw a conclusion by taking an example from the European situation. As long as West Germany uses Turkey as its Bantustan, from which it fetches workers (whose childhood and education costs have been paid by their parents and the Turkish society) when it needs them, and sends them back when it no longer needs them or when they become old, sick or unemployed, it seems difficult to do much by changing things in the schools in West Germany. Still, at the same time as progressive people work for the political changes needed in order to give minorities human conditions in West Germany, preparation for change is needed in schools, too. It is necessarily a defensive strategy, a defensive line of argumentation, that must be used, as long as societal conditions do not allow the type of offensive strategies we use in Scandinavia, and as long as the results of using an offensive strategy might be misused so as to strengthen the segregation.

We migrants in the Scandinavian countries, especially those of us who come from the other Scandinavian countries, cannot be thrown out, and that provides a

The worldwide spread of English has led to local variants becoming established, first in North America, later in Third World countries. There is now an increasing tendency to regard such "nativized" forms as Indian English or West African English as authentic local norms. Native speakers of these variants represent the norm (Kachru, 1986) even in tituations where they may have English as their second language. Thus "exposure to native speaker language" may be a more varied concept than the one implicit in the text (see also Phillipson, 1986). 


\section{MULTILINGUALISM AND THE EDUCATION}

different basis for our work. The defensive strategy, necessary in openly linguicist countries like West Germany, thus involves using arguments to legitimize the minority mother tongue in schools, which emphasize its instrumental value in learning the majority language. The offensive strategy used in Scandinavia emphasizes the human rights argument for legitimizing the minority mother tongues. The defensive line of argumentation may later on function as a negative boomerang, because the argument itself is linguicist. But choice of argument to be used is determined by the stage at which the society in question finds itself in the historical development of minority education.

In the final section we shall look at these stages. Who is to blame, according to the analyses on which different measures are based? Whose fault is it thought to be that minority children experience difficulties in school? Is it the child who is deficient, or is the society that controls the school "deficient", i.e. linguicist and racist?

\section{DEFICIENT CHILDREN OR DEFICIENT SCHOOLS AND SOCIETIES?}

We shall chart stages in the development of minority education in different countries. This is partly based on a report by Stacy Churchill for OECD, Centre for Educational Research and Innovation (CERI) (see Churchill, 1985). The readers are invited to look at the measures in their own countries and communities and try to place them in the scheme. What has been done, based on what problem definition, and with what goal? Table 1.4 summarizes the development.

When minority children experience problems in school, a reason for the problems is diagnosed, explicitly or implicitly. Then measures are suggested and taken to alleviate the problems. Behind the measures one can also discern an opinion about the future of the minorities: are these going to (be allowed to) maintain their languages and cultures, or are they going to disappear fast, or in some generations, to be assimilated into the majority? If they are not going to be assimilated immediately, is this seen as good and positive or bad and divisive for the society?

The first four phases in the development which most countries seem to be going through are based on deficit theories. There is something wrong with the minority child (1, L2-related handicap: the child does not know enough of the majority language), the minority parents (2, socially conditioned handicap: the parents are working class), the whole minority group ( 3 , culturally conditioned handicap: the child's cultural background is "different"), or all of these (4, L1-related handicap: the child does not know her own language and culture properly, and this leaves her without a firm basis for L2-learning, and gives her poor self-confidence). To a small extent there may also be something lacking in majority individuals (not systems), peers and teachers who may discriminate, because they have not had enough information. 
In these four phases it is envisaged that the minority should become majoritylanguage-speaking fast $(1,2)$. But as long as children still speak their original mother tongue, the school should help them to appreciate it $(3,4)$. The main measures depend on wich specific handicap the child is thought to suffer from. It seems that the measures from earlier phases are continued when the school system moves to the next phase.

Different European countries seem to show a somewhat different course of development. In Scandinavia, especially Sweden, we have focused much on the language handicaps ( 1 and especially 4 ). This has been mainly because of us Finns. We are the largest immigrant group in Sweden, and our social structure and cultural traits are relatively close to those of Sweden, partly as a result of the 650 years of colonization by Sweden. We Finns differ from the Swedes mainly in relation to language. Swedish is Indo-European, Northern Germanic; Finnish is Finno-Ugric, not related at all. The United Kingdom/Queendom has focused on cultural differences (3), in addition to the L2-related handicap (1), and the mother tongue deprivation discussions have barely started. West Germany has focused more on the social handicap explanantions (2), in addition to cultural and linguistic L2related handicaps, specially in relation to the largest migrant minority group, people from Turkey.

When one looks at the measures on a pan-European level, most energy just now is being spent on measures based on the later phases in the cultural deficiency explanation. The interculturalism seen in government declarations and invading all Europen teacher in-service training courses and new curricula is important to analyse because it still represents deficiency models, even if the package in which it is served (ethnicism and linguicism) is much more appetizing than was the old "racism-based-on-biological-differences".

It is also important to note that many of the measures, taken on the basis of the different explanations of reasons for problems, may be needed in many ways. It is good for minority children to have additional tuition in L2 and to learn more about their own culture, and it is useful that majority children and teachers learn something about minority cultures. And it is, as we have shown, necessary for minority children to develop their mother tongues in MT-medium programmes. But it is the basisfor these measures which is wrong. All of them, even the mother tongue deprivation model, see the child as deficient and lacking, and try to compensate for the "deficiencies", in order for the child to change to fit the school. It is still considered to be a deficiency in European schools to have another mother tongue and cultural background than the majority of the pupils and not to be middle class (and a boy).

The enrichment theories start from the conception that schools should be adapted to the children, not vice versa. The child's mother tongue and cultural and social background should be a positive starting point for the school. The existence 
TABLE 1.4

\begin{tabular}{lll}
\hline Reasons for problems & Measure
\end{tabular}

Deficit theories

1. Linguistic L2-related handicap, learning (the child does not master L2 well enough)

2. Social handicap, socially linked learning deficit (the child's parents come from lowest social classes)

3. Cultural handicap, culturally linked learning deficit (the child has a "different" cultural background; the child has low self-confidence; the child is discriminated against

\section{Linguistic L1-related} handicap, learning deficit because of $L 1$ deprivation (the child does not know her own $\mathrm{L}$ properly and has therefore poor grounding for the learning of L2 CALP) (the child loses content while learning L2)
More teaching of MaL (auxiliary teaching, ESL, introductory classes etc); compensatory

More social and pedagogical Same as 1

help (aids, tutors, psychologist, social workers, career advisers etc); in addition to measure 1; compensatory.

Inform MI-children about MAculture/about their own culture; inform all children about MIcultures/start multicultural/ intercultural educational programmes; eliminate discrimination/racism in teaching materials; attitudinal coursesfor teachers; in addition to measures 1 and 2; compensatory

Teaching of $L 1$ as subject; Same as 3 elementary education through the medium of $L 1$ with as fast a transition to L2-medium as possible. MiL has no intrinsic value, it is therapeutic; compensatory (more self-confidence, better co-operation with home, gives better basis for MaL-learning, functions as bridge for transmission of content during L2-learning); in addition to measures 1 and 3
MI is to become MaL-speaking as fast as possible

MiL in the family 1-2 generations MI-children need help to appreciate MI-culture (until they become MaL speaking) 
TABLE 1.4 (cont.)

\section{Enrichment theories}

5. High levels of bilingualism beneficial for the individual but difficult to attain, demands much work and energy. The primary goal is to learn MaL properly; it is a prerequisite for equal opportunity

\section{Bilingualism enhances development. If problems arise, the causes are similar to those of monolingual children; some problems may be caused by racism/discrimination}

Teaching through the medium of MiL for several years inside MA-school; obligatory teaching of MaL; transition to MaL medium teaching after elementary education

Separate, equal school systems for MI and MA children, L1 is medium for both and L2 obligatory (or possible to study) for both.Positive discrimination the M1 economically (smaller units allowed)
MiL allowed to be mantained for private use; bilingualism necessary; MiL is allowed to exist (in a diglossic situation as long as demographic basis exists

Existence of
minorities is en-
riching for the
whole society.
MiL has (at least
some) official
status and its use
is encouraged
also for MaL
children

Existence of minorities is enriching for the whole society. MiL has (at least some) official status and its use is encouraged children

$\mathrm{MI}=$ minority $; \mathrm{MiL}=$ minority language; $\mathrm{MA}-$ majority; $\mathrm{MaL}=$ majority language.

for minorities is seen as costly but enriching for societies, and bilingualism/ biculturalism is seen as beneficial and stimulating for the child. If minority children experience problems in school, these may be due to the extra work involved (5) or, in the last phase (6), either to similar reasons as for monolingual children or to these and racism, linguicism and discrimination. Only the last phase impliestransformative change (see Mullard, 1985a); all the others are more on less liberal/reformist. And it is only the last phase which can start to combat linguicism.

The only labour immigrant minority in the world which has come to the first enrichement phase is Finns in Sweden. I am disgregarding both (1) temporarily immigrated élites, NATO officers, diplomats, oil experts, international businesswomen and civil servants, etc., and (2) labour migrants who have set up their own schools at their own expense, without financial support from the receiving country. We are thus talking about education inside the ordinary state-supported educational system. 
Very few minorities in the world have come to phase 6, if we think of minorities in terms of numbers. It is indicative that the best protected educational rights among this type of numerical minorities are enjoyed by present of former power minorities (such as white South Africans, a present power minority, or Swedishspeakers in Finland, a former power minority, descendants of former colonizers). It is thus indicative of the importance of political factors that until now not many countries have accepted the existence of minorities as an enrichement, unless these minorities have or have had the power to dictate the conditions. In some situations where there are equal minorities on both sides of the border (German-speakers in Denmark, Danish-speakers in Germany), this has been achieved. Some minorities in socialist countries have also succeeded. Many of these, for instance Yugoslavia, do organize the education of minorities in ways where the non-socialist countries have much to learn (see Bugarski (forthcoming); Göncz (forthcoming); Institute for Ethnic Studies, Ljubljana, 1985: Lük Necak, 1985; Mikes, 1984; Petrovic \& Blagojevic, 1985). The USSR has done the same (see Drobizheva, 1986; Grigulevich \& Kozlov (eds), 1981; Guboglo, 1986). Some minorities in a few Third World countries have come far, too, for instance in India (Ekka, 1984; Pattanayak, 1981). And some of the well-organized labour migrant minorities might succed, too, if we know what we are doing and why. There is a wealth of international experience to share, because the linguicism is the same.

\section{CONCLUSION}

Trying to summarize extremely complicated matters in a short paper necessarily entails huge overgeneralizations, and the argumentation is to some extent crude shorthand (for a more detailed exposition see my Bilingualism or not: the education of minorities, 1984, 378 pages). A few general remarks in conclusion are of necessity even more shorthand.

High levels of bilingualism/biculturalism benefit every child, but for minority children bilingualism is a necessity. It is possible to achieve, if the main principle is followed, which seems to hold across different situations: support via all institutional measures the language which is otherwise less likely to develop in the cognitively demanding decontextualized register.

This language which otherwise does not get the chance, is for the minority children their mother tongue, and for power majorities (such as English-speakers in Canada) a minority language. These are the "easy" cases. But what about the others?

If several minorities together form the majority, the choice of ME should reflect the power relations between the minority groups and the group whose language they want to learn as their second language. The weaker the minority groups, the stronger the emphasis on their own language. But being educated through the 
medium of one's own language and wanting to become bilingual necessitates either much contact with that second language and good teaching in it, given by bilingual well-trained teachers (as in the Uzbekistan case), or, if there is little contact with the second language (as in Zambia where there is little contact with native English-speakers), extremely good teaching in that language (wich Zambia does not have). The absolute degrading of African languages during the colonial period and through neo-colonial economic politics and its concomitant ideology has produced a colonized consciousness, where the African languages are in a weak position (and need all the support schools can give), even when the former colonial power is no longer physically present with armies (see Angula, 1984; Kalema, 1980, 1985; Mateene, 1980a and b, 1985a and b; Phillipson, 1986).

Very few educational programmes in Europe for migrant minorities try to make the children bilingual, even if many claim that they do. They practise linguicism, as we have shown. But why do they do that? If we as linguists tell them that all languages are of equal worth, and make them aware of the problems, might they not change? If we tell them how minority children should be educated in order for them to reach high levels of bilingualism and to achieve at school, would they not organize education accordingly. ${ }^{9}$ Is it not a question of lack of information? The answer is a simple no.

Western industrial countries will need cheap labour at home in the future, too. The shitwork still needs to be done by somebody in Western countries. ${ }^{10} \mathrm{The}$ Third World produces much of the raw materials, food, clothing and equipment that we use. The exploitation of those countries now just takes different, more invisible forms than slavery and colonization, but it is at least equally severe. But we cannot export all of our cleaning, cooking, sweeping, public transport and washing up, or our sick and old, to be taken care of in the Third World, as easily as we export capital. Therefore, the industrial world needs to educate the children of the migrants, the great-grandchildren of the slaves from the colonies, for these jobs.

\footnotetext{
9You can often hear school administrators say that they would like to adhere to some of the principles referred to in this chapter, and indeed instruct minority children through the medium of their mother tongues. But it just so happens that they have 49 different languages in one single school (a situation which is not unusual), and therefore they can do nothing. It is impossible to justify that one group gets such instruction, when the 48 others do not. This is, with due respect to the practical difficulties involved, a false argument. There are many innovative ways of solving most of the problems, if the political will exists (small classes, age-integrated classes, bussing, firm long-term planning which guarantees instruction through the medium of certain languages at certain places for a long time so that people with those mother tongues can move to where they know there will be instruction, co-operation across school district (and even country) borders, summer, camps, guaranteeing young minority people teacher jobs in advance if they promise to undergo training, etc., etc.). In most cases practical arguments are used to mask the real arguments, and the issue of principle is avoided.
} 


\section{MULTIIINGUALISM AND THB EDUCATION}

Therefore, minority education needs to be racist and linguicist, in order to force the great-grandchildren of the slaves to continue to take the shitwork. In this it has succeeded.

Why so much fuss about language, then, if all these things are decided politically, anyway? -if what is best for a child linguistically, cognitively, pedagogically and socially does not count?-if language, in addition to that, can mislead our engagement so that we don't see how it is used in the interculturalism celebration to fool us, to prevent us from seeing the same old racism in its cultural clothes, in the assimilationist ethricism? -and if power is all that matters anyway?

For three reasons, at least:

- we need our language for analysis. Without a thorough analysis we struggle in the dark

- we need our language for solidarity, both with our contemporaries, and across generations

- we need bilinguals as mediators. Those who are bi-something (bilingual, bidialectal, bicultural) have been forced to look at two different languages, dialects, cultures from the inside. It is easier for us bilinguals to understand both parties.

In a world at five to twelve ( $=0$ the verge of self-destruction) what is needed is not monolingual technical idiots (white, middle-class, male) who can make the missile and push the button. They are people who have never been forced to and who are probably not able to see matters from the inside from somebody else's point of view. You can obviously not discuss with a missile, but a real bilingual/ bicultural might be able to mediate before the button is released, provided she has the instruments for analysis, and the solidarity.

It may be time for linguists also to realize that linguicism is not a bunch of illwilled, misinformed individuals. It is not a question of information, but of power structure. Obviously, it is our job as linguists to produce information, but unless we know whose question we ask in our research and why, we may unknowingly provide arguments for supporting linguicism and racism, especially the hidden, unconscious, invisible kind, which is the most difficult one to detect and to fight. A poster I have on my study door has, as a part of the devastating and beautiful picture by Malaquias Montoya, a text by G. R. Castillo: "One day the apolitical intellectuals of my country will be interrogated by the simplest of our people". Researchers are some sort of intellectuals, too, aren't we?

\section{REFERENCES}

AFRICA, H. 1980. Language in education in a multilingual state: a case study of the role of English in the educational system of Zambia.Ph. D. Dissertation, Toronto: University of Toronto. 
ANGULA, N. 1984."English as a medium of communication for Namibia: Trends aand possibilities". In Commonwealth Secretariat \& Swapo 1984.

BUGARSKI, R. (forthcoming), "Language policy and language planning in Yugoslavia". To appear in French in J. MAURAIS (ed.), $L$ ' aménagement linguistique comparé. Quebec \& Paris: Conseil de la langue francaise, le Robert.

CALVET, L. J. 1974. Linguistique et Colonialisme. Petit Traité de Glottophagie. Paris: Petite Bibliotèque Payot.

CHISHIMBA, M. M. 1984. "Language policy and education in Zambia". International Education Journal 1984.

CHURCHILL, S. 1984. The education of linguistic and cultural minorities in the $O E C D$ countries. Clevedon: Multilingual Matters 13.

COMMONWEALTH SECRETARIAT \& SWAPO 1984. English Language Programme for Namibians. Seminar Report, Lusaka, 19-27 October 1983.

CUMMINS, J. 1984. Bilingualism and special education: Issues in assessment and pedagogy. Clavedon: Multilingual Matters 6.

DROBIZHEVA, L. 1986. "Social and psychological aspects of inter-ethnic relations in the USSR". In Y. V. ARUTIUNIAN (ed.), Multilingualism: Aspects of interpersonal and intergroup communication in pluricultural societies. Moscow: Institute of Ethnography of the Academy of Sciences of the USSR.

EKKA, F. 1984. "Status of minority languages in the schools of India". International Education Journal 1984.

GIDDENS, A. 1973, The class structure of the advanced societies. London: Hutchinson.

GRIGULEVICH, I. R. \& S. Ya. Kozlov (eds.) 1981. Ethnocultural processes and national problems in the modern world. Moscow: Progress Publishers.

GÖNCZ, L. (forthcoming), "Psychological studies of bilingualism in Vojvodina". In Yugoslavian General Linguistics.

GUBOGLO, M. 1986. "Language and communication in Soviet society".In Y. V. Arutiunian (ed.), Multilingualism: Aspects of interpersonal and intergroup communication in pluricultural societies. Moscow: Institute of Etnhography of the Academy of Sciences of the USSR.

INSTITUTE FOR ETHNIC STUDIES (Ljubljana) 1985. "Some Yugoslav experiences in the achievement of the equality of the nations and nationalities in the field of education". Paper presented at the National seminar on Education in multicultural societies. Ljubljana, 15-17 October.

K.ACHRU, B. B. 1986. The alchemy of English.The spread, functions and models of non-native Englishes. Oxford: Pergamon Press.

KALEMA, J. 1980. "Report on functions and activities of the OAU Inter African Bureau of Languages". In K. Mateene \& J. Kalema (eds.), 1980. 1985. Introduction. In K. Mateene, J. Kalema \& B. Chomba (eds.). 1985.

LAMBERT, W. 1975. Culture and languages as factors in learning and education. In A. Wolfgang (ed.). 
LAMBERT, W. \& D. Taylor 1982. "Language in the education of ethnic minority inmigrants: Issues, problems and methods." Paper presented to Conference on Education of Ethnic Minority Immigrants, Miami.

LUK NECAK, A. 1985. "Education in multicultural societies and its social implications". Paper presented at the National seminar on education in multicultural societies. Ljubljana, October.

MATEENE, K. 1980a, Introduction. In K. Mateene, \& J. Kalena (eds.). 1980b. "Failure in the obligatory use of European languages in Africa and the advantage of a policy of linguistic independence". In K. Mateene \& J,. Kalema (eds.).

1985a. "Colonial languages as compulsory means of domination, and indigenous languages, as necessary factors of liberation and development". In K. Mateene, J. Kalema \& B. Chomba (eds.).

— 1985b. "Reconsideration of the official status of colonial languages in Africa". In K. Mateene, J. Kalema \& B. Chomba (eds.).

MATEENE, K. \& J. Kalema 1980. Reconsideration of african linguistic policies. Kampala: OAU Bureau of Languages, OAU/BIL Publication 3.

MATEENE, K., J. Kalema \& B. Chomba (eds.). 1985. Linguistic liberation and unity of Africa. Kampala: OAU Bureau of Languages, OAU/BIL Publication 6.

MIKES, M. 1984. "Instruction in the mother tongue in Yugoslavia". Prospects, XIV:1.

MULLARD, C. 1985a. "Racism, ethnicism and etharchy or not? The principles of progressive control and transformative change". This volume, Ch. 17; originally presented as a plenary paper at the International Symposium on Minority Languages in Academic Research and Educational Policy, Sandbjerg Slot, Denmark, April 1985.

- 1985b. Race, power and resistance. London: Routledge \& Paul Kegan.

PATTANAYAK, D. P. 1981, Multilingualism and mother tongue education. Delhi: Oxford University Press. 1986. Educational use of the mother tongue. In B. Spolsky (ed.).

PETROVIC, R. \& M. Llagojevic, 1985. The educational structure of ethnic groups in Yugoslavia. Paper presented at the National seminar on Education in multicultural societies, Ljubljana, 15-17 October.

PHILLIPSON, R. 1986. The rule of English. In R. Phillipson \& T. SkutnabbKangas.

PHILLIPSON, R. \& T. Skutnabb-Kangas. 1983. Multilingualism-papers in cultural and communicative (in) competence. ROLIG-paper 28, Roskilde Universitetscenter.

1986. Linguiscism rules in education, 3 volumes, Roskilde University Centre, Institute VI: Roskilde.

PHILLIPSON, R., T. Skutnabb-Kangas \& H. Africa. 1986. Namibian educational language planning: English for liberation or neo-colonialism? In B. Spolsky (ed.). 


\section{Tove Skutnabb-Kangas}

SKUTNABB-KANGAS, T. 1984. Bilingualism or not: the education of minorities. Clevedon: Multilingual Matters 7.

- 1986. Who wants to change what and why-conflicting paradigms in minority education research. In B. Spolsky (ed.).

SPOLSKY, B. (ed.) 1986. Language and education in miltilingual settings. Clevedon: Multilingual matters 25.

SWAIN, M. \& S. Lapkin. 1982. Evaluating bilingual education: A Canadian case study. Clevedon: Multilingual Matters.

WOLFGANG, A. (ed.) 1975. Education of immigrant students. Toronto: Ontario Institute for Studies in Education. 